\title{
Enhancing Business Integrity as a Mechanism for Combating Corruption and Shadow Schemes in the Country
}

http://doi.org/10.21272/bel.5(3).97-101.2021

Victoria Bozhenko, ORCID: https://orcid.org/0000-0002-9435-0065

$\mathrm{PhD}$, Associate Professor of the Economic Cybernetics Department, Sumy State University, Ukraine

\begin{abstract}
This paper summarizes the arguments and counterarguments within the scientific discussion on the relationship between business integrity and corruption in the country. The main purpose of the research is to analyze the mechanism of the business integrity impact on combating corruption and shadow economy in the country and identify key triggers for violating the business integrity principles. The relevance of this scientific problem is that corruption is gradually turning from a domestic problem into a global threat, which requires changing the combating and detecting corruption instruments. Investigation of the relationship between the corruption level in the country and the shadow economy scale in the paper is carried out in the following logical sequence: at first, scientific publications on corruption and integrity in the corporate sector are monitored, then, current and retrospective levels of corruption in Ukraine and the world are assessed and triggers of breach the business integrity principles are identified. Methodological tools of the research methods were empirical (observation, description) and theoretical (grouping, synthesis, abstraction) research methods. A comprehensive analysis of corruption from the standpoint of the diachronic relationship between wrongdoers and recipients has shown that bribery costs will outweigh the benefits to the entity in the long run. According to the results of the study, it is established that breach of the integrity principles by business representatives arise due to gaps in the regulatory framework and unregulated by law certain aspects of the enterprise; non-transparent procedure of interaction with public authorities; low working conditions for state regulation, supervision and control bodies; lack of a formalized procedure for lobbying the interests of stakeholders in public authorities; high level of oligarchization in society. The article substantiates that the creation of a culture of business integrity will have a synergistic effect on the development of the national economy by increasing transparency and transparency of public authorities, increasing foreign investment, increasing the competitiveness of domestic products at the international level, implementing innovative projects, improving welfare.
\end{abstract}

Keywords: Business Integrity, Corruption, Shadow Economy, Compliance System.

JEL Classification: D73, O17, L26.

Cite as: Bozhenko, V. (2021). Enhancing Business Integrity as a Mechanism for Combating Corruption and Shadow Schemes in the Country. Business Ethics and Leadership, 5(3), 97-101. http://doi.org/10.21272/bel.5(3).97-101.2021.

Received: 04 June 2021

Accepted: 10 August 2021

Published: 13 September 2021

Copyright: (C) 2021 by the author. Licensee Sumy State University, Ukraine. This article is an open access article distributed under the terms and conditions of the Creative Commons Attribution (CC BY) license (https://creativecommons.org/licenses/by/4.0/).

\section{Introduction}

In modern conditions, corruption is gradually turning from a domestic problem into a global threat. Currently, countries worldwide (including those with developed economies) are reviewing tools and methods of combating corruption, adopting new laws and regulations to strengthen accountability for corruption. The Corruption Perceptions Index, calculated by Transparency International, shows that in 2020 more than twothirds of countries scored less than 50 points, which is evidence of an ineffective system of anti-corruption measures. All this necessitates the study of modern practices to improve standards of compliance and business integrity, which will build a competitive and profitable business, as well as increase trust among customers and partners.

Today, there is a growing recognition that integrity is vital to running a profitable and stable business. First, it is a response to the increasing attention of regulators and legislators to the issue of integrity and business ethics; secondly, the growing role of ESG factors (environmental, social effects and corporate governance) in investment decisions; thirdly, companies' awareness of significance to do business responsibly. 


\section{Literature Review}

Corruption is a destabilizing factor in developing economic relations, contributing to the unfair competitive conditions for businesses, increasing the unequal distribution of income among the population, etc. Corruption and the shadow economy are complex and multifaceted processes that can complement each other and be interdependent. In particular, the author proved that a high level of corruption perception in the country leads to a decrease in foreign investment (Nguedie, 2018). Kaya et al. (2021) compares the crisis with the post-crisis period and finds that informal payments have decreased significantly since the end of the global economic crisis.

Juarez-Garcia (2020) argues a dual nature of the corruption implementation schemes: the first level - corruption among government officials, the second level - the legal framework imperfection, which allows for illegal activities and lack of proper punishment for it. The literature notes that small companies are more likely to receive or offer bribes than large companies (Pelizzo et al., 2016). Svensson (2003) shows that civil servants tend to demand fewer bribes from companies with greater bargaining power, the main factor of which is the size of the firm. At the same time, smaller firms are less likely to have strong internal controls to detect corruption. In contrast, some of the consequences of corruption described below (e.g., staff morale and business relationships) will operate according to different dynamics (Serafeim, 2014).

In addition to the enterprise's size, the issue of business integrity is also studied in the context of ownership. The most pressing issue of business integrity has arisen for state-owned enterprises. (OECD, 2018) surveyed 347 representatives in 213 state-owned enterprises across 34 countries and found that four out of five state enterprises allocated an average of $1.5 \%$ of the operating budget to detect and eliminate corruption and integrity violations in the previous year. Most state-owned enterprises have an internal audit, public disclosure, assessment of anti-corruption and integrity risks in risk management, as well as organized channels of complaints and advice on reporting offenses.

Jenkins (2017) empirically confirms that companies with anti-corruption programs and clear ethical principles face 50\% more corruption than companies without them, which proves the effectiveness of such integrity programs to minimize losses and increase the profitability of companies. Guerrero and Urbano (2020) demonstrated that formal (state programs) and informal institutions (corruption, extortion and illegal trade) have a statistically significant impact on the development of technological initiatives of enterprises to protect victimization. Modern digital transformations increase the level of integrity among the corporate sector and minimize corruption risk in doing business. In particular, the paper (Wahab, 2019) analyzes the impact of the scalable business reporting language (eXtensible Business Reporting Language) and blockchain on the level of corporate reputation, as well as the protection of confidential data.

\section{Methodology and Research Methods}

The main purpose of the research is to analyze the mechanism of the business integrity impact on combating corruption and shadow economy in the country and identify key triggers for violating the business integrity principles. Methodological tools of the research methods were empirical (observation, description) and theoretical (grouping, synthesis, abstraction) research methods.

\section{Results}

The pervasive nature of corruption hampers the country's social and economic development, undermines the principles of a democratic society, and exacerbates inequality and injustice, distorting the rule of law and punishing victims of crime through corrupt decisions. Corruption exists separately from any activity and extends to all areas of socio-economic relations. Even with the high tax competitiveness of the state and the favorable conditions for attracting investment in the state, the presence of corruption offsets all existing benefits. For Ukraine, the problem of corruption is very acute. According to the Global Corruption Barometer (2016), conducted annually by the international organization Transparency International, almost every fourth citizen of Ukraine offers a bribe to receive public services of the appropriate quality. According to a poll conducted by the Ilko Kucheriv Democratic Initiatives Foundation, it was determined that in 2017 a quarter of the population of Ukraine gave bribes to medical institutions (46\%), higher and secondary educational institutions (22\%), local authorities (14\%), schools (10\%), patrol police (9\%) (Sukharina, 2017). These statistics reveal another significant factor in stimulating corruption in Ukraine: the population's mentality, which solves any difficulties and problems through bribery. At the same time, the results of the National AntiCorruption Survey show that in 2021, $78 \%$ of Ukrainians consider corruption to be one of the most serious 
problems in society (USAID). Analytical confirmation of the high level of corruption in all spheres of life in Ukraine is the corruption perception index (Figure 1).

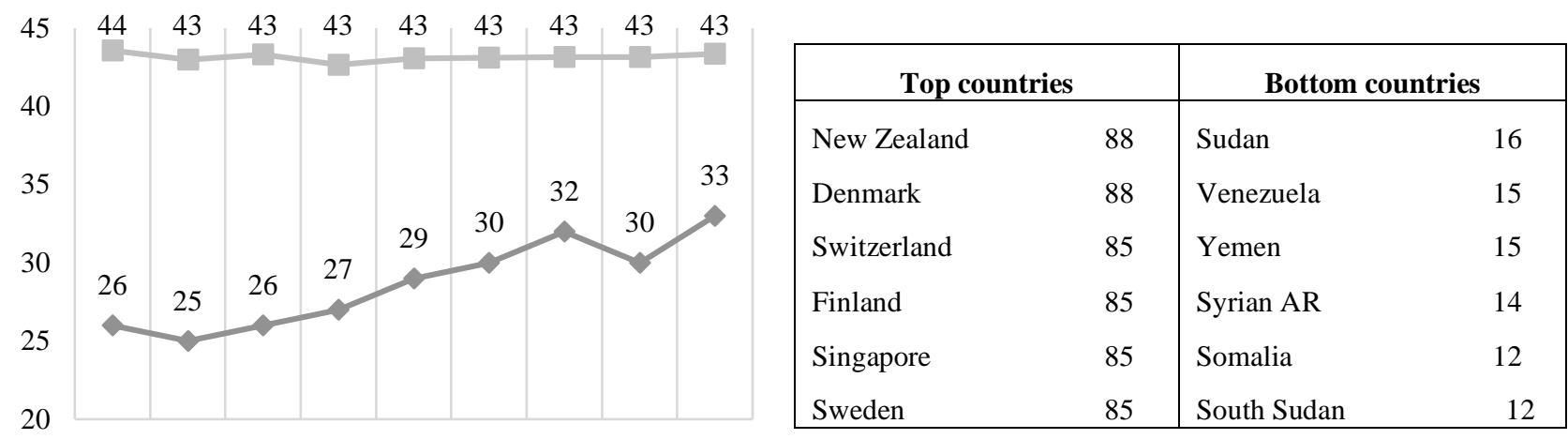

201220132014201520162017201820192020

$\leadsto$ Ukraine - -World

Figure 1. Corruption Perception Index in Ukraine and Some Countries of the World in 2021, units

Source: The World Bank

As Figure 1 shows, during 2012-2020, the corruption perception index in Ukraine was in the range of 26-33 units. Despite a slight improvement in the fight against corruption in 2021, Ukraine still has a significant level of corruption in the relations of economic agents with the authorities. The level of the corruption perception index in Ukraine is lower than the world's average (43 units). The top countries on the CPI are Denmark and New Zealand, with scores of 88, followed by Finland, Singapore, Sweden, and Switzerland, with 85 each. The bottom countries are South Sudan and Somalia, with scores of 12 each, followed by Syria (14), Yemen (15), Venezuela (15) and Sudan (16). Since 2012, 26 countries have improved their CPI scores, including Greece, Myanmar and Ecuador. In the same period, 22 countries decreased their scores, including Lebanon, Malawi and Bosnia \& Herzegovina.

Thus, in a highly interconnected world, the fight against corruption and its negative consequences cannot be successful without the coordinated and consistent interaction of the public sector, the business community, civil society and citizens at both the national and international levels. To overcome it, the inevitability of punishment for corruption in the country must become the norm for all members of society, regardless of their material security and status. The issue of ensuring integrity in the corporate sector of the economy is interdisciplinary, as the relationship between business integrity or its absence and performance of the entity, as well as its impact on various spheres of public life: economics, politics, social and legal spheres, is the subject of research many scientists from around the world.

A comprehensive analysis of corruption from the standpoint of the diachronic relationship between the providers of illicit benefits and its recipients shows that the cost of bribery will outweigh the benefits to the entity in the long run. Because offering an illegal financial benefit to an official or other business entity is a very resource-intensive procedure, which leads to the release of significant financial resources from the company's turnover. For example, the case of Siemens indicates that the estimated cost of bribery is about 3\% of total turnover (Serafeim, 2014). In addition, companies that do not follow the principles of business integrity, in the long run, will experience a slowdown in development and reduced productivity of their activities, increasing the cost of attracting financial resources.

Transparency International defines business integrity from the standpoint of adherence to generally accepted ethical standards, regulations, and the promotion of responsible core values (honesty, fairness, trust, etc.). Businesses that follow legal and ethical business standards avoid informal relationships with employees, contractors, and regulators. Civil society also plays an important role in preventing, reducing and responding to corruption and shadow schemes. Triggers for branch the principles of business integrity in Ukraine can be the following:

gaps in the regulatory framework and unregulated by law certain aspects of the enterprise, which allows, first, to carry out legal business activities in violation of the requirements for its documentation and reporting; secondly, they make it impossible to conduct an effective investigation and bring violators to justice; 
non-transparent procedure of interaction with public authorities in obtaining licenses and permits, privatization of state property, public procurement, determination of the tax base, administration of taxes and fees, etc.;

$>$ low working conditions for state regulatory, supervisory and control bodies, which include an insufficient level of wages and social guarantees, which can easily push them to accept illegal benefits from business representatives;

$>$ the lack of a formalized procedure for lobbying the interests of stakeholders in public authorities. A legally recognized institution of lobbying will improve the quality of legislative support in the country and its stability through the cooperation of scientists, research centres and specialists in the relevant field to make informed state and local decisions.

a high level of oligarchization in society, which allows them to dictate market conditions: the establishment of import duties and quotas, low rents for mining, special tariffs for electricity and gas to consumers, low prices for the use of state railways and pipelines, control over state enterprises, etc.

According to Transparency International, the state of business integrity in the country is the result of interaction between stakeholders in the public and private sectors and civil society, and is formed based on the following components (OECD, 2016):

$>$ public environment, which reflects the state of legislation and practice of the country to prevent, reduce and respond to corruption in business (28 indicators);

$>$ corporate environment, which assesses the actions of the private sector of the economy in relation to corruption and shadow schemes in the country (12 indicators);

civic initiatives to combat and prevent corruption in the public and private sectors (3 indicators).

In September 2021, a business integrity assessment has been conducted for a small number of countries (Serbia, Turkey, Mongolia, Cambodia, Mozambique, Romania, Kenya, Trinidad and Tobago, and others). The anti-corruption NGO Transparency International Ukraine has not yet conducted a comprehensive study to assess the level of business integrity in the country.

The issue of business integrity is also included in the list of priority areas of the Organization for Economic Cooperation and Development (OECD) research. Experts of this organization believe that improving the governance and transparency of state-owned enterprises is one of the key measures of the government to promote business integrity in Eastern Europe and Central Asia (OECD, 2017). Because 80 percent of bribe recipients from foreign companies were representatives of state-owned enterprises (OECD, 2014). This is because state-owned enterprises operate in an area where the principles of the private and public sectors are often intertwined. In this regard, in 2019, the OECD adopted Guidelines for the Fight against Corruption and Integrity in State-Owned Enterprises (OECD, 2019).

Thus, strengthening the principles of business integrity will reduce the manifestation of corruption and crimes in the sphere of official activity in the decision-making process of public authorities and their officials and build an ethical culture of doing business. Creating a culture of business integrity will have a synergistic effect on the development of the national economy by increasing foreign investment, increasing the competitiveness of domestic products at the international level, implementation of innovative projects, improving the welfare of the population, etc.

\section{Conclusion}

To provide an attractive institutional environment for attracting foreign investment and increasing the business activity of businesses, corruption needs to be addressed as part of a private sector development strategy. Given the dominant role of the private sector in shaping the country's GDP, promoting awareness of the fight against corruption and the development of standards of ethical conduct in business is extremely important.

Funding. This research was funded by the grant from the Ministry of Education and Science of Ukraine (No. s/r 0121U100467, 0121U109559, 0120U100473).

\section{References}

1. Global Corruption Barometer (2016). People and corruption: Europe and Central Asia. Transparency International. Available at: [Link]

2. Jenkins, M. (2017). The relationship between business integrity and commercial success U4 AntiCorruption Resource Centre, Chr. Michelsen Institute. Available at: [Link] 
3. Juarez-Garcia, M.I. (2020). Personal Corruption \& Corrupting Laws: Montesquieu's Twofold Theory of Corruption. Business Ethics and Leadership, 4(4), 76-84. [Google Scholar] [CrossRef]

4. Kaya, H.D., Engkuchik, E.N.S. (2021). The Perception of Corruption Among Retailers in Central Asia and Eastern Europe During and After the 2008 Crisis. SocioEconomic Challenges, 5(2), 70-80. [CrossRef]

5. Mujtaba, B.G., McClelland, B., Williamson, P., Khanfar, N., Cavico, F.J. (2018). An Analysis of the Relationship between Regulatory Control and Corruption based on Product and Market Regulation and Corruption Perceptions Indices. Business Ethics and Leadership, 2(3), 6-20. [Google Scholar] [CrossRef]

6. Nguedie, Y. H. N. (2018). Corruption, Investment and Economic Growth in Developing Countries: A Panel Smooth Transition Regression Approach. SocioEconomic Challenges, 2(1), 63-68. [Google Scholar] [CrossRef]

7. OECD (2014). OECD Foreign Bribery Report: An Analysis of the Crime of Bribery of Foreign Public Officials. [CrossRef]

8. OECD (2016). Business Integrity Country Agenda (2016). Conceptual Framework for a BISA Assessment. Available at: [Link]

9. OECD (2017). Business Integrity in Eastern Europe and Central Asia (2017). Summary Report. 2017. Available at: [Link]

10.OECD (2018). Promoting integrity and preventing corruption in state-owned enterprises: What works and what does not? in State-Owned Enterprises and Corruption: What Are the Risks and What Can Be Done? OECD Publishing. 45-94. [CrossRef]

11.OECD (2019). Guidelines on Anti-Corruption and Integrity in State-Owned Enterprises. Available at: [Link]

12.Pelizzo, R., Araral, E., Pak, A., Wu, X. (2016). Determinants of Bribery: Theory and Evidence from subSaharan Africa. African Development Review, 28(2), 229-240. [Google Scholar] [CrossRef]

13.Serafeim, G. (2014). Firm Competitiveness and Detection of Bribery. Harvard Business School Working Paper, 14-012. [Google Scholar] [CrossRef]

14.Svensson, J. (2003). Who Must Pay Bribes and How Much? Evidence from a Cross-Section of Firms. The Quarterly Journal of Economics, 118(1), 207-230. [Google Scholar] [CrossRef]

15.Sukharina, A. (2017). Domestic corruption: what Ukrainians think about it. Public Opinion, 31. Available at: [Link]

16.Transparency International (2009). Policy Position, Building Corporate Integrity Systems to Address Corruption Risks. Available at: [Link]

17.The World Bank. CPI Score. Available at: [Link]

18.USAID (2021). 14 years of corruption in the perception and experience of Ukrainians. Available at: [Link]

19.Wahab, Z. Abd. (2019). Integrating XBRL and Block Chain to Improve Corporate Transparency Integrity and Availability in Malaysia. International Journal of Academic Research in Business and Social Sciences, 9(6). [Google Scholar] [CrossRef] 